International Journal of Current Advanced Research

ISSN: O: 2319-6475, ISSN: P: 2319 - 6505, Impact Factor: SJIF: 5.995

Available Online at www.journalijcar.org

Volume 6; Issue 3; March 2017; Page No. 2494-2495

DOI: http://dx.doi.org/10.24327/ijcar.2017.2495.0035

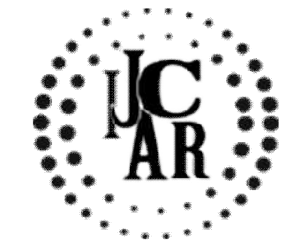

Research Article

\title{
DETECTION OF TAU IN THE RETINA
}

\section{Umur Kayabasi and Marco Rispoli}

Soyak Yenișehir, Manolya Evleri A-2 No:50 Ümraniye, Turkey

\section{A R T I C L E I N F O}

\section{Article History:}

Received $8^{\text {th }}$ December, 2016

Received in revised form $19^{\text {th }}$ January, 2017

Accepted $12^{\text {th }}$ February, 2017

Published online $28^{\text {th }}$ March, 2017

\begin{abstract}
A B S T R A C T
Purpose: To show different types of Tau tangles by retinal examination.

Methods: 30 patients with early or advanced Alzheimer's (AD) were examined by OCT and FAF.

Results: Different types of tau tangles were detected in different stages of the disease.

Conclusion: Retinal examination can reveal AD pathology non-invasively.
\end{abstract}

Key words:

Tau; OCT; FAF, Retina; Alzheimer's

Copyright $₫ 2017$ Umur Kayabasi and Marco Rispoli. This is an open access article distributed under the Creative Commons Attribution License, which permits unrestricted use, distribution, and reproduction in any medium, provided the original work is properly cited.

\section{INTRODUCTION}

Recent studies suggest that amyloid beta (BA) induced Taupathology is responsible for the severe outcome of Alzheimer's Disease (AD) process. Data from different models support the thesis in which BA accumulation acts as a triggering event in the pathogenetic process by accelerating antecedent Tau.(1) Abnormal aggregation of tau protein ultimately leads to the formation of tangles with in nerve cells. Once initiated, the tau aggregation process continues and spreads into previously healthy cells.(2) There are three main charecteristics for a taupathy: (a) an increase in taulevels ; (b) a modification, like hyperphosphorylation, sometimes related to another post translational modifications such as truncation or acetylation; and (c) an abnormal tau aggregation.(2)

\section{METHODS}

Patients with early or advanced AD had spectral domain optical scanning tomography (SD-OCT) and fundus auto fluorescein (FAF) tests. Retinal regions with hyperorhypo fluorescence were in spected by OCT and neuro fibrillary filaments (Figure 1) and advanced Tau tangles (Figure 2) were detected in a masked fashion.
*Corresponding author: Umur Kayabasi Soyak Yenişehir, Manolya Evleri A-2 No:50 Ümraniye, Turkey
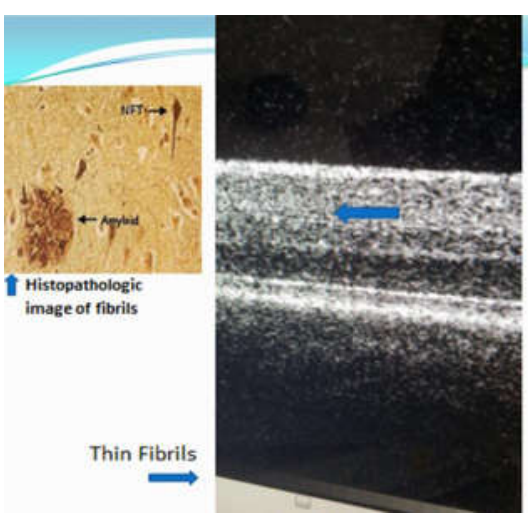

Figure 1

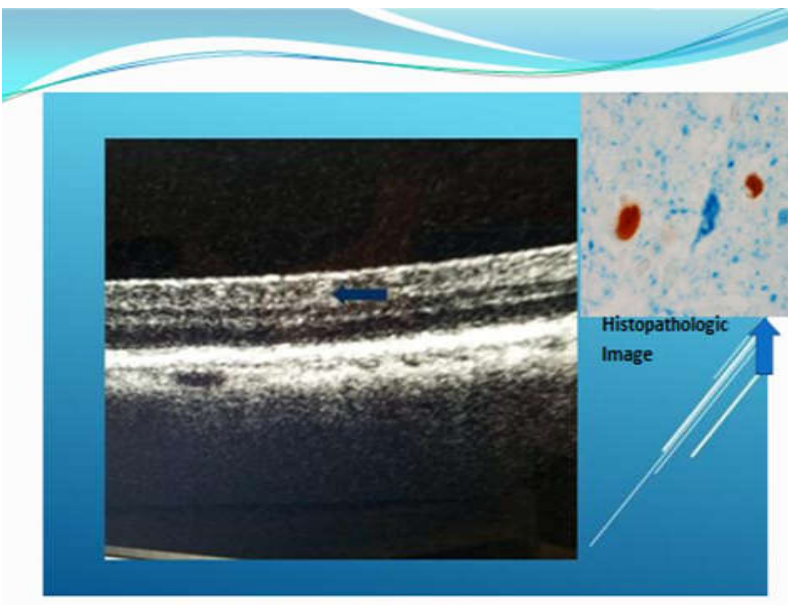

OCT image of an advanced stage Tau Tangle

Figure 2 


\section{RESULTS}

Inpatients with early $\mathrm{AD}$ ormild cognitive impairment (MCI), mostly thin filaments were seen on OCT. But, in the patients with PET-proven advanced $\mathrm{AD}$, apart from beta amyloid plaques thick tangles could be detected. Some of the thick tangles had a reverse E or number 3 shape. (Figure 2)

\section{DISCUSSION}

Retinal examination for amyloid beta is important, but may not be enough to diagnose AD since it can be found in other diseases or just ageing. (3) Detecting BA triggered Tauaggregates may be more specific. And staging of AD may be possible by retinal examination and detection of Tau in different development stages.(4)

\section{CONCLUSION}

Retinal examination by OCT and FAF is safe, non-invasive and cheap; plus, OCT and FAF are valuable and trustable biomarkers in the diagnosis of $\mathrm{AD}$.

\section{References}

1. Goedert, M. Neurodegeneration. Alzheimer's and Parkinson's diseases: The prion concept in relation to assembled $A \beta$, tau, and $\alpha$-synuclein. Science 2015.

2. JaumeFolch, Dmitry Petrov, MirenEttcheto, et al. Current Research Therapeutic Strategies for Alzheimer's Disease Treatment. Neural Plasticity. Volume 2016 (2016): Article ID 8501693.

3. Umur Kayabasi, Robert C Sergott, and MarcoRispoli. Retinal Examination for the Diagnosis of Alzheimer's Disease. Int J Ophthalmol ClinRes 2014, 1:1.

4. Umur Kayabasi. Tau in the Retina. EC Neurology3.5 (2016): 493-499.

\section{How to cite this article:}

Umur Kayabasi and Marco Rispoli (2017) ' Detection Of Tau In The Retina ', International Journal of Current Advanced Research, 06(03), pp. 2494-2495.

DOI: http://dx.doi.org/10.24327/ijcar.2017.2495.0035 